\title{
Preparation, Characterization, and Antioxidant Features of Some New Schiff Bases Derived from Isatins and Hydrazine
}

\author{
Halit MUĞLU ${ }^{1 *}$, Hasan YAKAN ${ }^{2}$
}

\begin{abstract}
New isatins based on Schiff bases were prepared from hydrazine, 5-substituted isatins, and aldehydes under reflux in ethanol. The structures of the synthesized compounds were elucidated by using IR, ${ }^{13} \mathrm{C}$ NMR, ${ }^{1} \mathrm{H}$ NMR spectroscopy and elemental analysis. All the compounds were tested in vitro antioxidant activity with free radical scavenging method using by 1,1-diphenyl-2-picryl hydrazyl (DPPH). The results were given with calculated $\mathrm{IC}_{50}$ values.

Keywords: Schiff bases, isatin, DPPH, antioxidant features, spectroscopic method.

\section{Hidrazin ve Isatinlerden Elde Edilen Bazı Yeni Schiff Bazlarının Sentezi, Karakterizasyonu ve Antioksidan Özellikleri}

ÖZET: Yeni schiff bazlı isatinler, hidrazin, 5-sübstitütentli isatinler ve çeşitli aldehitlerin etil alkolde geri soğutucu altındaki tepkimesi sonucu elde edilmiştir. Sentezlenen bileşiklerin yapısı IR, ${ }^{13} \mathrm{C}$ NMR, ${ }^{1} \mathrm{H}$ NMR spektroskopik veriler ve elementel analiz sonuçlar ile aydınlatılmıştır. Sentezlenen bileşiklerin antioksidan aktivite testleri 2,2-difenil-1-pikril hidrazil (DPPH) radikal giderme yöntemi ile yapılmıştır. Sonuçlar, hesaplanan $\mathrm{IC}_{50}$ (yarı maksimum inhibitör derişim) değerleri ile verilmiştir.

Anahtar Kelimeler: Schiff bazı, isatin, DPPH, antioksidan özellikler, spektroskopik yöntem.

\footnotetext{
${ }^{1}$ Halit MUĞLU (Orcid ID: 0000-0001-8306-2378), Kastamonu University, Faculty of Science, Department of Chemistry, 37150, Kastamonu, Turkey

${ }^{2}$ Hasan YAKAN (Orcid ID: 0000-0002-4428-4696), Ondokuz Mayis University, Faculty of Education, Department of Chemistry, 55139, Samsun, Turkey

*Sorumlu Yazar/Corresponding Author: Halit MUĞLU, e-mail: hmuglu@kastamonu.edu.tr
}

Geliş tarihi / Received: 08-07-2019 Kabul tarihi / Accepted: 28-11-2019 


\section{INTRODUCTION}

Isatins are a significant group of organic compounds owing to their importance potential application in medicinal chemistry and biological activity such as anti-bacterial (Chohan et al., 2004), anti-viral (Jarrahpour et al., 2007; Abbas et al., 2013), anti-fungal (Sinha et al., 2008), anti-oxidant (Andreani et al., 2010; Naik et al., 2011; Premanathan et al., 2012; Kiran et al., 2013) anti-convulsant (Sridhar et al., 2002), anti-tubercular (Aboul-Fadl and Bin-Jubair, 2010; Liang et al., 2014; Gabr et al., 2017), anti-HIV (Pandeya et al., 2000; Bal et al., 2005).

Schiff bases of bearing isatin are known to have a wide range of pharmacological and biological properties. They were reported as anti-convulsant (Verma et al., 2004), anti-bacterial (Chohan et al., 2004; Jarrahpour et al., 2007), anti-viral (Jarrahpour et al., 2007; Abbas et al., 2013), anti-oxidant (Kiran et al., 2012; Bakır et al., 2018) , anti-HIV (Pandeya et al., 2000; Bal et al., 2005) and anti-fungal activity (Pandeya et al., 2000; Chohan et al., 2004; Jarrahpour et al., 2007).

We studied that new isatins based on Schiff bases were prepared two stages. First, hydrazine and 5 -substituted isatins react with to give intermediate product under reflux in ethanol. Second, intermediate product and aldehydes react with to give isatins based on Schiff bases in the presence of a drop $\mathrm{HCl}$ under reflux in ethanol. They were determined by using IR, ${ }^{1} \mathrm{H}$ NMR, ${ }^{13} \mathrm{C}$ NMR spectroscopy, elemental analysis. All the compounds were tested by 1,1-diphenyl-2-picryl hydrazyl (DPPH) free radical trapping method for in vitro antioxidant activity. The results were given with calculated $\mathrm{IC}_{50}$ values.

\section{MATERIALS AND METHODS}

\section{Measurement and Reagents}

All reagents and solvents were used without further purification and purchased from Aldrich, Sigma, or Merck Chemical Company. The solvents were spectroscopic grade. The elemental analysis was measured on Eurovector EA3000-Single. Melting points were determined using Stuart Melting Point 30 apparatus. IR spectra were taken on the Bruker Alpha FT-IR spectrometer. ${ }^{1} \mathrm{H}$ and ${ }^{13} \mathrm{C}$ NMR spectra were taken on JEOL ECX-400 (400 MHz) in DMSO- $d_{6}$ spectrophotometer. Absorption measurements were recorded with SHIMADZU UV Pharmaspec 1700 spectrophotometer.

\section{Synthesis 5-Substituted Isatin-Hydrazones Based on Schiff Bases (1-5)}

5-Substituted isatins $(5 \mathrm{mmol})$ and hydrazine $(5 \mathrm{mmol})$ in ethanol-water mixture $(3: 1,40 \mathrm{~mL})$ were stirred and refluxed for 3-5 h. Then, the reaction mixture reacts with equimolar amount of various aldehydes in a drop $\mathrm{HCl}$ as catalyst in the presence of ethanol $(40 \mathrm{~mL})$ for 3-5 h. After finishing reaction, the mixture was filtered and washed with ethanol. The formed solid was isolated and dried to give the products 1-5 as shown in Scheme 1.

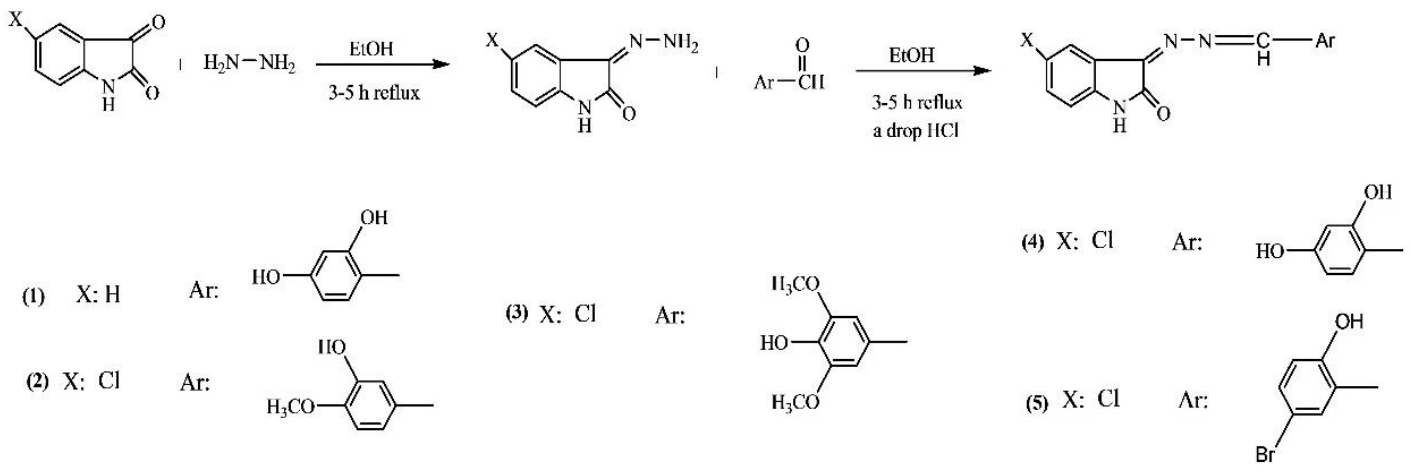

Scheme 1. General synthesis of 5-substituted isatin based on Schiff bases 


\section{Antioxidant Activity}

DPPH was used in ethanol at a concentration of $55 \mu \mathrm{M}$ so as to evaluate the antioxidant activity of the synthesized compounds. Stock solutions of the compounds were prepared in DMSO to $250 \mu \mathrm{M}$. To the previously prepared (4 mL) DPPH solution were added compound solutions of different concentrations $(0.25,0.50,1.00,2.50,5.00 \mu \mathrm{M})$ and enough ethanol to a total of $5 \mathrm{~mL}$. This mixture could stand in a dark room at room temperature for 30 minutes and then read at $517 \mathrm{~nm}$ against a blank (Blois 1958; Manjula et al., 2015).

The percentage inhibition of the free radical concentration for the sample compounds was calculated and compared to the standard Trolox. Radical scavenging activity was expressed as a percentage of inhibition and calculated using formulas:

Radical scavenging activity $(\%)=\left[\left(\mathrm{A}_{0}-\mathrm{A}_{1}\right) / \mathrm{A}_{\mathrm{o}} \mathrm{x} 100\right]$

Where $A_{o}$ is the absorbance of the control (blank, without compound) and $A_{1}$ is the absorbance of the compound (Naik et al., 2011; Meral and Doğan, 2012).

In addition, $\mathrm{IC}_{50}$ values were calculated from the calibration curve. The $\mathrm{IC}_{50}$ value is defined as the concentration of the test compound required to obtain half maximum inhibition, and the low $\mathrm{IC}_{50}$ value indicates more antioxidant activity (Frankel et al., 2000).

\section{RESULTS AND DISCUSSION}

\section{Physical Data}

All the synthesized compounds were new. The current experimental results for the physical data, melting points, yields, and elemental analyses are summarized in Tables 1 and 2.

Table 1. The physical data, melting points, and yields for the synthesized compounds

\begin{tabular}{lllll}
\hline Compounds & Mol. Weight $\left(\mathbf{g ~ m o l}^{-\mathbf{1}}\right)$ & Solubility & Melting Point $\left.\mathbf{~}^{\mathbf{0}} \mathbf{C}\right)$ & Yields $(\%)$ \\
\hline $\mathbf{1}$ & 329.74 & DMSO (+) & $>350$ & 62 \\
$\mathbf{2}$ & 359.77 & DMSO (+) & $258-259$ & 80 \\
$\mathbf{3}$ & 281.27 & DMSO (+) & $276-278$ & 60 \\
$\mathbf{4}$ & 315.72 & DMSO (+) & $>350$ & 65 \\
$\mathbf{5}$ & 378.61 & DMSO (+) & $293-295$ & 90 \\
\hline
\end{tabular}

Table 2. The results for elemental analysis for the synthesized compounds

\begin{tabular}{lllllll}
\hline \multirow{2}{*}{ Compounds } & \multicolumn{3}{c}{ Calculated } & \multicolumn{3}{c}{ Experimental } \\
\cline { 2 - 7 } & $\mathbf{N}$ \% & $\mathbf{C ~ \%}$ & H \% & $(\mathbf{N})$ \% & (C) \% & (H) \% \\
\hline $\mathbf{1}$ & 12.74 & 58.28 & 3.67 & 12.62 & 57.66 & 3.56 \\
$\mathbf{2}$ & 11.68 & 56.76 & 3.92 & 10.91 & 55.56 & 3.75 \\
$\mathbf{3}$ & 14.94 & 64.05 & 3.94 & 13.98 & 64.20 & 3.79 \\
$\mathbf{4}$ & 13.31 & 57.07 & 3.19 & 13.21 & 56.28 & 2.98 \\
$\mathbf{5}$ & 12.21 & 52.35 & 2.93 & 11.85 & 51.65 & 2.78 \\
\hline
\end{tabular}

\section{Vibrational Frequencies}

At the end of the reaction, the aldehyde group (-CHO) signal was not observed near 2750-2650 $\mathrm{cm}^{-1}$. Also, the asymmetric and symmetric stretching bands of the amino group $\left(-\mathrm{NH}_{2}\right)$ were not appeared at 3600-3200 $\mathrm{cm}^{-1}$. These results indicated a successful reaction as expected. In compound $\mathbf{2}$, the $-\mathrm{OH}$ peak of aryl region was observed at $3357 \mathrm{~cm}^{-1}$, the $-\mathrm{NH}$ stretching vibration of isatin ring was observed at $3237 \mathrm{~cm}^{-1}$; the $\mathrm{C}=\mathrm{O}$ signal of isatin ring was observed at $1721 \mathrm{~cm}^{-1}$, the $-\mathrm{C}=\mathrm{N}$ stretching vibration was appeared at $1591 \mathrm{~cm}^{-1}$; the $-\mathrm{C}-\mathrm{N}$ stretching vibration was observed at $1179 \mathrm{~cm}^{-1}$; the $-\mathrm{C}$ $\mathrm{O}$ signal of aryl ring was observed at $1068 \mathrm{~cm}^{-1}$, the $-\mathrm{C}-\mathrm{Cl}$ signal was observed at $894 \mathrm{~cm}^{-1}$ as shown in 
Figure 1. Furthermore, IR peaks of the compounds are given in the Table 3. These frequency values of the synthesized compounds are agreement with the similar compounds (Pandeya et al., 2000; Jarrahpour et al., 2007; Bekircan and Bektas, 2008).

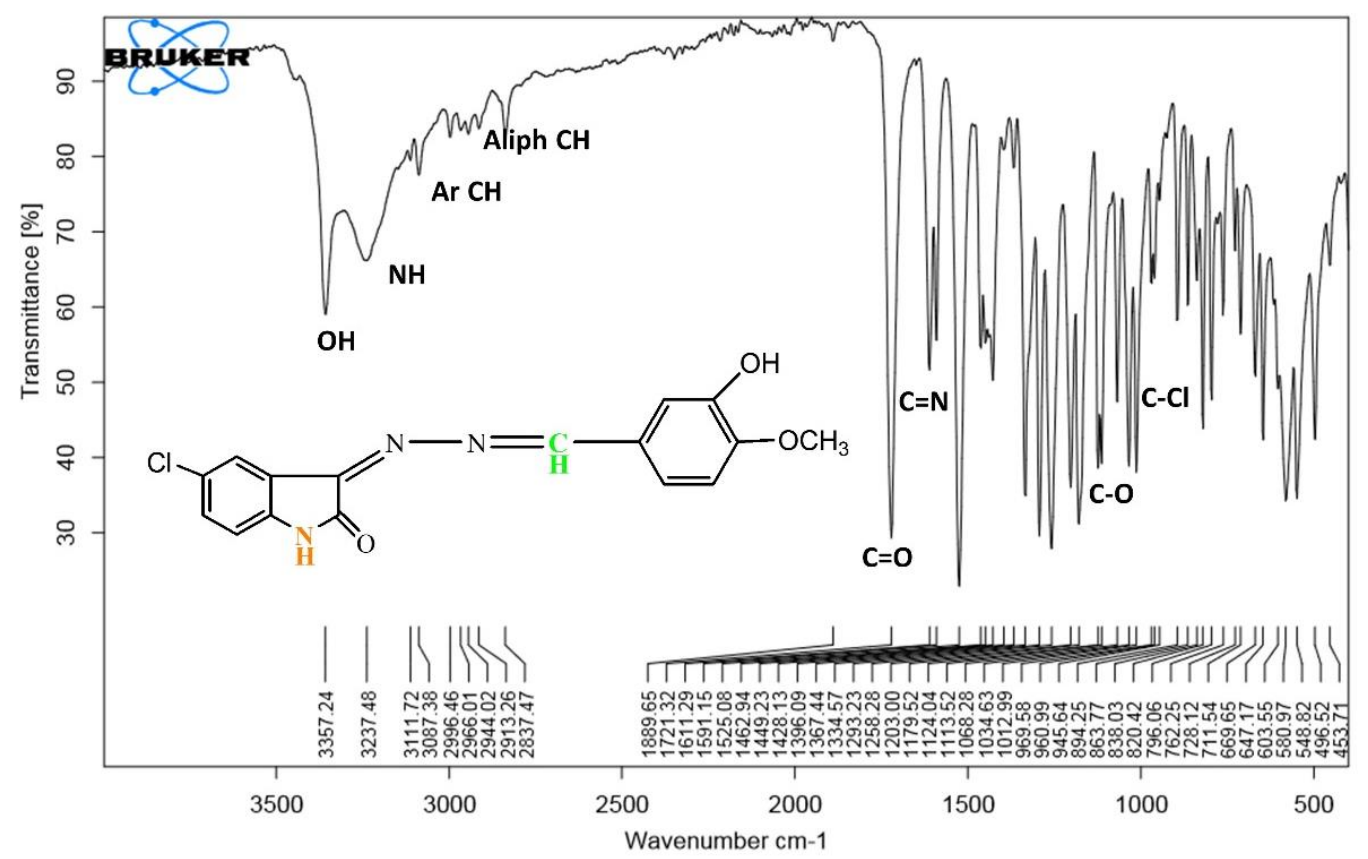

Figure 1. FT-IR spectrum of compound 2

Table 3. Experimental FT-IR values of the compounds $\left(\mathrm{cm}^{-1}\right)$

\begin{tabular}{lllllllll}
\hline Comp. & -OH & -NH & Ar CH & Aliph CH & C=O & C=N & C-O & C-Cl \\
\hline $\mathbf{1}$ & 3312 & 3241 & $3082-3014$ & $2976-2856$ & 1713 & 1542 & 1081 & 887 \\
$\mathbf{2}$ & 3357 & 3237 & $3111-3087$ & $2966-2837$ & 1721 & 1591 & 1068 & 894 \\
$\mathbf{3}$ & 3302 & 3242 & $3096-3007$ & $2972-2844$ & 1738 & 1532 & 1074 & 893 \\
$\mathbf{4}$ & 3332 & 3136 & $3078-3012$ & $2966-2842$ & 1720 & 1571 & 1073 & 857 \\
$\mathbf{5}$ & 3313 & 3239 & $3092-3016$ & $2981-2869$ & 1734 & 1616 & 1071 & 895 \\
\hline
\end{tabular}

\section{${ }^{1}$ H NMR Spectral Interpretation}

The ${ }^{1} \mathrm{H}$ NMR spectra of the synthesized compounds were detected in DMSO- $d_{6}$ as solvent and showed general scheme for ${ }^{1} \mathrm{H}$ NMR spectral interpretations in Scheme 2.

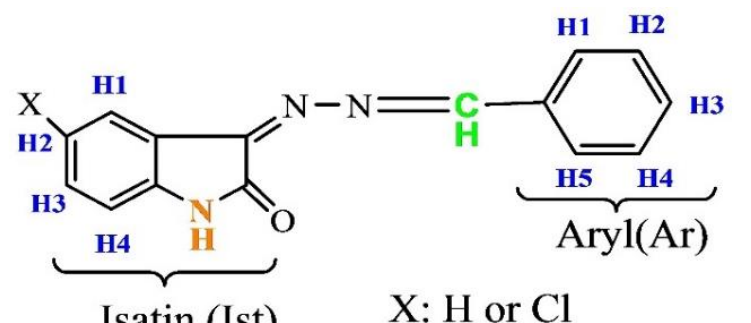

Isatin (Ist)

$\mathrm{X}: \mathrm{H}$ or $\mathrm{Cl}$

1-5

Scheme 2. General scheme for ${ }^{1} \mathrm{H}$ NMR spectral interpretations

For compound 5, the $\mathrm{H} 5$ aromatic proton signal of aryl ring was observed as a singlet at $7.76 \mathrm{ppm}$. The $\mathrm{H} 3$ proton of aryl ring coupled to the $\mathrm{H} 2$ and $\mathrm{H} 5$ proton and observed doublet of doublets peaks at 
$6.88 \mathrm{ppm}$. The $\mathrm{H} 2$ proton of aryl ring coupled to the $\mathrm{H} 3$ proton and showed doublet peaks at $6.90 \mathrm{ppm}$. The signal of imin $(-\mathrm{CH}=\mathrm{N})$ was observed as a singlet at $8.89 \mathrm{ppm}$. The $-\mathrm{NH}$ signal of isatin was observed as a singlet at $11.09 \mathrm{ppm}$. The -OH signal of aryl ring was observed as a singlet at $7.85 \mathrm{ppm}$. The aromatic protons signals of isatin ring $(\mathrm{H} 1-\mathrm{H} 4)$ were observed between 7.17 and $7.49 \mathrm{ppm}$. The $\mathrm{H} 1$ proton of isatin was observed singlet peak at $7.17 \mathrm{ppm}$. The $\mathrm{H} 3$ proton of isatin coupled to the $\mathrm{H} 1$ and $\mathrm{H} 4$ proton and observed doublet of doublets peaks at $7.49 \mathrm{ppm}$. The $\mathrm{H} 4$ proton of isatin coupled to the $\mathrm{H} 3$ proton and showed doublet peaks at $7.44 \mathrm{ppm}$ as shown in Figure 2. DMSO- $d_{6}$ and water in DMSO (HOD, $\mathrm{H} 2 \mathrm{O}$ ) signals are shown around at 2.00, 2.50 (quintet) and 3.30 (variable, based on the solvent and its concentration) ppm, respectively (Fleming and Williams, 1966). These data are consistent with the values of earlier reported for similar compounds (Pandeya et al., 2000; Jarrahpour et al., 2007; Bekircan and Bektas, 2008). Proton chemical shift values of the synthesized compounds are given in the Table 4.

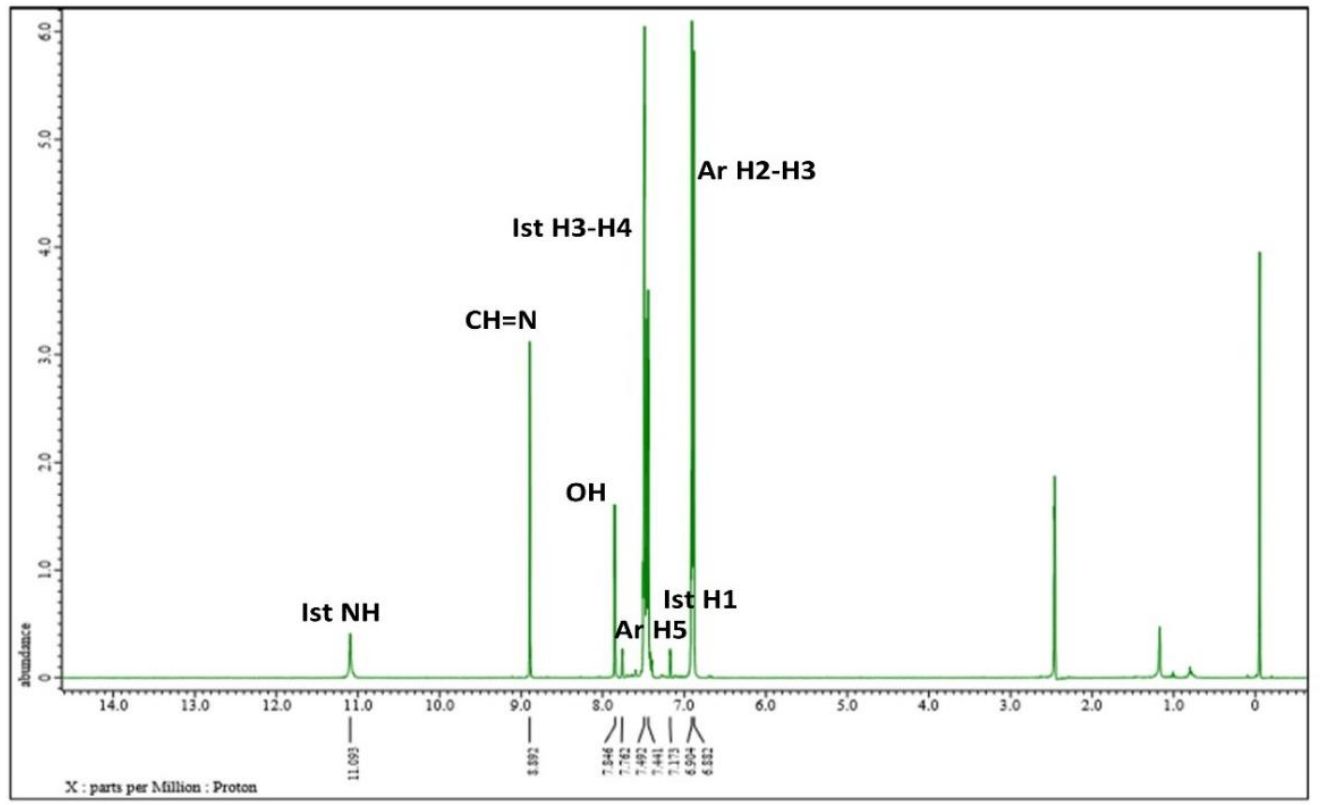

Figure 2. ${ }^{1} \mathrm{H}$ NMR spectrum of compound 5

Table 4. ${ }^{1} \mathrm{H}$ NMR values of the synthesized compounds ( $\delta$, ppm, in DMSO- $\left.d_{6}\right)$

\begin{tabular}{lccccccccccccc}
\hline Comp. & $\mathbf{C H}=\mathbf{N}$ & $\mathbf{A r}$ & $\mathbf{A r}$ & $\mathbf{A r}$ & $\mathbf{A r}$ & $\mathbf{A r}$ & $\mathbf{I s t}$ & $\mathbf{I s t}$ & $\mathbf{I s t}$ & $\mathbf{I s t}$ & Ist & $\mathbf{- O H}$ & $\mathbf{O C H}_{\mathbf{3}}$ \\
& & $\mathbf{H 1}$ & $\mathbf{H 2}$ & $\mathbf{H 3}$ & $\mathbf{H 4}$ & $\mathbf{H 5}$ & $\mathbf{N H}$ & $\mathbf{H 1}$ & $\mathbf{H 2}$ & $\mathbf{H 3}$ & $\mathbf{H 4}$ & & \\
\hline $\mathbf{1}$ & 9.88 & - & 8.88 & - & 7.73 & 8.02 & 10.97 & 6.99 & 6.87 & 6.40 & 7.46 & 10.89 & - \\
& & & & & & & & & & & & 10.78 & \\
$\mathbf{2}$ & 8.76 & 6.87 & - & - & 7.08 & 7.40 & 9.72 & 8.55 & - & 7.34 & 7.96 & 7.86 & 3.83 \\
$\mathbf{3}$ & 8.59 & 8.10 & - & - & - & 8.10 & 11.10 & 7.27 & - & 6.88 & 7.45 & 7.75 & 3.83 \\
$\mathbf{4}$ & 9.87 & - & 7.38 & - & 6.88 & 6.45 & 10.97 & 6.84 & - & 7.46 & 7.68 & 8.86 & - \\
& & & & & & & & & & & & 8.01 & \\
$\mathbf{5}$ & 8.89 & - & 6.90 & 6.88 & - & 7.76 & 11.09 & 7.17 & - & 7.49 & 7.44 & 7.85 & - \\
\hline
\end{tabular}

\section{${ }^{13}$ C NMR Spectral Interpretation}

The ${ }^{13} \mathrm{C}$ NMR spectra of the synthesized compounds were detected in DMSO- $d_{6}$ as solvent and showed general scheme the spectral interpretations in Scheme 3. 


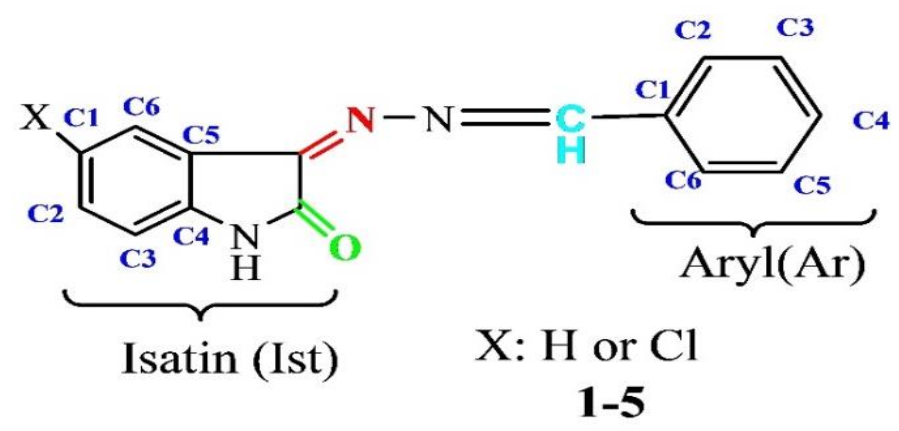

Scheme 3. General scheme for ${ }^{13} \mathrm{C}$ NMR spectral interpretations

For compound 2, the $-\mathrm{C}=\mathrm{O}$ signal of isatin region was detected at $165.0 \mathrm{ppm}$. The characteristic $\mathrm{CH}=\mathrm{N}$ (imin) peak was observed at $144.1 \mathrm{ppm}$. The characteristic $-\mathrm{C}=\mathrm{N}$ peak of isatin ring was observed at $150.4 \mathrm{ppm}$. The methoxy $\left(-\mathrm{OCH}_{3}\right)$ peak was detected at $56.3 \mathrm{ppm}$ as shown in Figure 3. The aromatic carbons (C1-C6) of aryl ring were observed at 126.5, 112.9, 164.6, 152.6, 112.6, and $128.5 \mathrm{ppm}$, respectively. The resonances of the $\mathrm{C} 3$ and $\mathrm{C} 4$ carbon atoms shifted down-field due to the presence of electron-withdrawing groups $-\mathrm{OCH}_{3}$ and $-\mathrm{OH}$, respectively. The aromatic carbons (C1-C6) of isatin region were also observed at 147.6, 124.1, 126.3, 133.3, 118.3, and $114.2 \mathrm{ppm}$, respectively. The resonances of the $\mathrm{C} 1$ and $\mathrm{C} 4$ carbon atoms shifted down-field due to the presence of electronwithdrawing groups $-\mathrm{Cl}$ and $-\mathrm{NH}$, respectively. These data are consistent with the values of earlier reported for similar compounds (Jarrahpour et al., 2007; Bekircan and Bektas, 2008; Özkınalı et al., 2018). The carbon chemical shift values of the synthesized compounds are given in the Table 5.

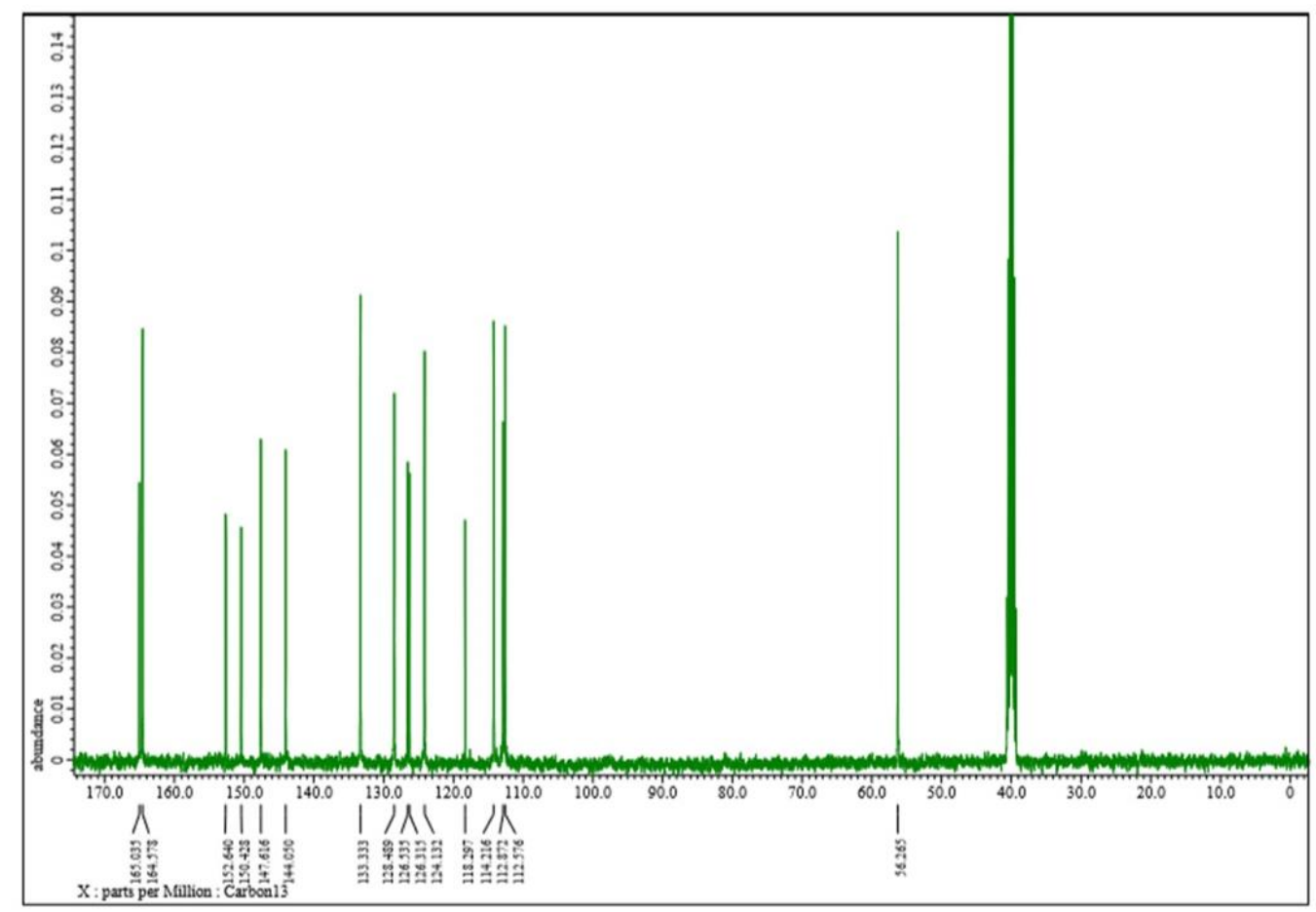

Figure 3. ${ }^{13} \mathrm{C}$ NMR spectrum of compound 2 
Table 5. ${ }^{13} \mathrm{C}$ NMR values of the synthesized compounds $\left(\delta\right.$, ppm, in DMSO- $\left.d_{6}\right)$

\begin{tabular}{|c|c|c|c|c|c|c|c|c|c|c|c|c|c|c|c|}
\hline omp. & $\begin{array}{l}\text { Ist } \\
\text { C1 }\end{array}$ & $\begin{array}{l}\text { Ist } \\
\text { C2 }\end{array}$ & $\begin{array}{l}\text { Ist } \\
\text { C3 }\end{array}$ & $\begin{array}{l}\text { Ist } \\
\text { C4 }\end{array}$ & $\begin{array}{l}\text { Ist } \\
\text { C5 }\end{array}$ & $\begin{array}{l}\text { Ist } \\
\text { C6 }\end{array}$ & $\begin{array}{c}\text { Ist } \\
\mathrm{C}=\mathbf{N}\end{array}$ & $\begin{array}{c}\text { Ist } \\
\mathrm{C}=\mathrm{O}\end{array}$ & $\mathrm{CH}=\mathrm{N}$ & $\begin{array}{l}\text { Ar } \\
\text { C1 }\end{array}$ & $\begin{array}{l}\text { Ar } \\
\text { C2 }\end{array}$ & $\begin{array}{l}\text { Ar } \\
\text { C3 }\end{array}$ & $\begin{array}{l}\text { Ar } \\
\text { C4 }\end{array}$ & $\begin{array}{l}\text { Ar } \\
\text { C5 }\end{array}$ & $\begin{array}{l}\text { Ar } \\
\text { C6 }\end{array}$ \\
\hline & 15 & 31 & 8.7 & 4.9 & 18 & 6 & $\overline{508}$ & 165.5 & 145.4 & 34. & 163 & 92 & 61.6 & 09.5 & 23.2 \\
\hline & & & 126.3 & & & & & & & & & & & & 28.5 \\
\hline & & & .5 & 7 & 5 & 2 & 3 & .5 & $\delta$ & .3 & 8 & & .6 & 3.7 & 13.2 \\
\hline & 137.8 & 127.8 & 126.1 & 131.8 & 112.8 & 111.6 & 149.9 & 3 & 143.9 & 133.0 & 164.6 & 103.1 & 161.9 & 109.7 & 118.3 \\
\hline b & 136.0 & 128.5 & 126.6 & 134.5 & 113.2 & 111.1 & 146.3 & 163.8 & 144.8 & 132.1 & 161.3 & 119.5 & 117.6 & 158.2 & 120.9 \\
\hline
\end{tabular}

\section{Evaluation of Antioxidant Activity}

Many biochemical reactions involve the production of reactive oxygen species (ROS) that cause cell damage and are controlled by the antioxidant defense system in the body (Kiran et al., 2012). This situation is protected by many antioxidant molecules and antioxidant enzymes. In recent years, many studies have shown that isatin derivative molecules exhibit synthetic antioxidant properties (Kiran et al., 2012; Andreani et al., 2010).

An antioxidant is defined as any substance that will delay or prevent the oxidation of the substrate, even when present at much lower concentrations than the oxidizable substrate (Wanasundara and Shahidi, 2005; Brewer, 2011; Shahidi, 2015; Uruk and Kahraman, 2017). In this study, IC 50 values were calculated at the end of DPPH analysis for the synthesized compounds and Trolox as shown in Table 6. The $\mathrm{IC}_{50}$ values of all test compounds were between 21.78 and $24.82 \mu \mathrm{M}$. Although compounds 1 and 2 had a slightly stronger antioxidant activity against DPPH radicals, the others exhibited very low activity compared to a strong $\mathrm{H}$ donor such as Trolox in Figure 4. Compound $\mathbf{2}$ had the strongest antioxidant activity among the synthesized compounds.

Table 6. $\mathrm{IC}_{50}$ values for the synthesized compounds

\begin{tabular}{lll}
\hline Compounds & DPPH activity $\mathrm{IC}_{50}(\mu \mathrm{M})$ \\
\hline $\mathbf{1}$ & 21.83 \\
$\mathbf{2}$ & 21.78 \\
$\mathbf{3}$ & 24.82 & \\
$\mathbf{4}$ & 24.44 & \\
$\mathbf{5}$ & 24.64 & \\
Trolox & 16.09 & \\
\hline
\end{tabular}

Kiran and co-workers studied antioxidant properties of isatin based on Schiff bases and $\mathrm{IC}_{50}$ values were measured between 26.56 and $57.40 \mu \mathrm{M}$ with DPPH method (Kiran et al., 2012). These values exhibited antioxidant activity lower than that of the present studies. The other study of Kiran and coworkers antioxidant properties of isatin derivatives and $\mathrm{IC}_{50}$ values were measured at between 20.56 and $58.70 \mu \mathrm{M}$ with DPPH method (Kiran et al., 2013). In this study, $\mathrm{IC}_{50}$ values were measured between 21.78 and $24.82 \mu \mathrm{M}$ with DPPH method. The results of this work showed that the synthesized compounds are remarkably scavenged by the DPPH free radical. These values corroborate the values of formerly reported similar compounds. 


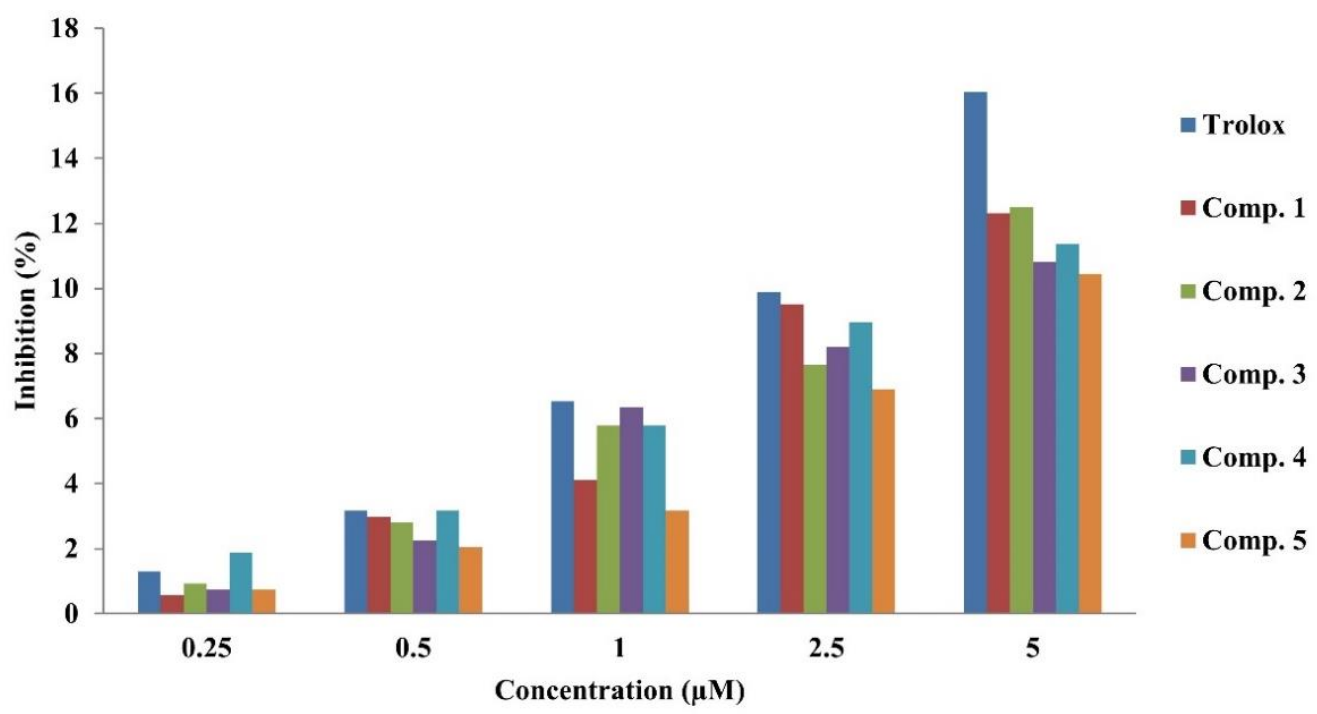

Figure 4. Variation of percent inhibition calculated by the DPPH method for Trolox and the compounds at different concentrations.

\section{CONCLUSION}

Some new isatin-hydrazones based on Schiff bases were synthesized with good yields of 60-90\%. All the compounds were elucidated by ${ }^{1} \mathrm{H}$ NMR, ${ }^{13} \mathrm{C}$ NMR, IR spectroscopy and elemental analyses. The in vitro antioxidant properties of the synthesized compounds were measured by the DPPH free radical trapping method and compared to the standard Trolox. Although compound $\mathbf{2}$ had the strongest antioxidant activity among the synthesized compounds, it had a lower antioxidant activity against DPPH radicals according to the standard Trolox.

\section{REFERENCES}

Abbas SY, Farag AA, Ammar YA, Atrees AA, Mohamed AF, El-Henawy AA, 2013. Synthesis, characterization, and antiviral activity of novel fluorinated isatin derivatives. Monatshefte für Chemie-Chemical Monthly, 144: $1725-1733$.

Aboul-Fadl T, Bin-Jubair FA, 2010. Anti-tubercular activity of isatin derivatives. International Journal of Research in Pharmaceutical Sciences, 1: 113-126.

Andreani A, Burnelli S, Granaiola M, Leoni A, Locatelli A, Morigi R, Rambaldi M, Varoli L, Cremonini MA, Placucci G, 2010. New isatin derivatives with antioxidant activity. European Journal of Medicinal Chemistry, 45: 1374-1378.

Bakır T, Sayiner HS, Kandemirli F, 2018. Experimental and theoretical investigation of antioxidant activity and capacity of thiosemicarbazones based on isatin derivatives. Phosphorus, Sulfur, and Silicon and the Related Elements, 193: 493-499.

Bal TR, Anand B, Yogeeswari P, Sriram D, 2005. Synthesis and evaluation of anti-HIV activity of isatin $\beta$ thiosemicarbazone derivatives. Bioorganic \& Medicinal Chemistry Letters, 15: 4451-4455.

Bekircan O, Bektas H, 2008. Synthesis of Schiff and Mannich bases of isatin derivatives with 4-amino-4, 5dihydro-1H-1,2,4-triazole-5-ones. Molecules, 13: 2126-2135.

Blois MS, 1958. Antioxidant determinations by the use of a stable free radical. Nature, 181(4617): 1199.

Brewer M, 2011. Natural antioxidants: sources, compounds, mechanisms of action, and potential applications. Comprehensive Reviews in Food Science and Food Safety, 10(4): 221-247.

Chohan ZH, Pervez H, Rauf A, Khan KM, Supuran CT, 2004. Isatin-derived antibacterial and antifungal compounds and their transition metal complexes. Journal of Enzyme Inhibition and Medicinal Chemistry, 19: 417-423.

Fleming I, Williams DH, 1966. Spectroscopic methods in organic chemistry: McGraw-hill New York. 
Frankel EN, Meyer AS, 2000. The problems of using one-dimensional methods to evaluate multifunctional food and biological antioxidants. Journal of the Science of Food and Agriculture, 80(13): 1925-1941.

Gabr MT, El-Gohary NS, El-Bendary ER, El-Kerdawy MM, Ni N, 2017. Isatin- $\beta$-thiocarbohydrazones: Microwave-assisted synthesis, antitumor activity and structure-activity relationship. European Journal of Medicinal Chemistry, 128: 36-44.

Jarrahpour A, Khalili D, De Clercq E, Salmi C, Brunel J, 2007. Synthesis, antibacterial, antifungal and antiviral activity evaluation of some new bis-Schiff bases of isatin and their derivatives. Molecules, 12: 1720-1730.

Kiran G, Maneshwar T, Rajeshwar Y, Sarangapani M, 2012. Microwave-assisted synthesis, characterization, antimicrobial and antioxidant activity of some new isatin derivatives. Journal of Chemistry 2013.

Kiran G, Sarangapani M, Gouthami T, Narsimha reddy AR, 2013. Synthesis, characterization, and antimicrobial and antioxidant activities of novel bis-isatin carbohydrazone derivatives. Toxicological \& Environmental Chemistry, 95: 367-378.

Liang C, Xia J, Lei D, Li X, Yao Q, Gao J, 2014. Synthesis, in vitro and in vivo antitumor activity of symmetrical bis-Schiff base derivatives of isatin. European Journal of Medicinal Chemistry, 74: 742-750.

Manjula P, Sarojini B, Raj CD, 2015. Antibacterial and in vitro antioxidant activities of some 4-amino-1,2,4triazole-5 (4H)-thione derivatives. Journal of Fundamental and Applied Sciences, 7(3): 394-407.

Meral R, Doğan, İ, 2012. Karadut (Morus nigra) Katk1lı Ekmeğin Antioksidan Aktivitesi ve Fenolik Kompozisyonu. Journal of the Institute of Science and Technology, 2(4): 43-48.

Naik N, Vijay Kumar H, Vidyashree PB, 2011. Synthesis and evaluation of antioxidant potential of novel isatin analogues. Journal of Pharmacy Research, 4: 2686-2689.

Özkınalı S, Gür M, Şener N, Alkın S, Çavuş M.S, 2018. Synthesis of new azo schiff bases of pyrazole derivatives and their spectroscopic and theoretical investigations. Journal of Molecular Structure, 1174: 74-83.

Pandeya SN, Sriram D, Nath G, De Clercq E, 2000. Synthesis, antibacterial, antifungal and anti-HIV evaluation of Schiff and Mannich bases of isatin and its derivatives with triazole. Arzneimittelforschung, 50: 55-59.

Premanathan M, Radhakrishnan S, Kulangiappar K, Singaravelu G, Thirumalaiarasu V, Sivakumar T, Kathiresan $\mathrm{K}, 2012$. Antioxidant \& anticancer activities of isatin (1H-indole-2, 3-dione), isolated from the flowers of Couroupita guianensis Aubl. Indian Journal of Medical Research, 136(5): 822-826.

Shahidi F, 2015. Antioxidants: Principles and applications. Handbook of antioxidants for food preservation: Woodhead Publishing, 1-14.

Sinha D, Tiwari AK, Singh S, Shukla G, Mishra P, Chandra H, Mishra AK, 2008. Synthesis, characterization and biological activity of Schiff base analogues of indole-3-carboxaldehyde. European Journal of Medicinal Chemistry, 43: 160-165.

Sridhar SK, Pandeya SN, Stables JP, Ramesh A, 2002. Anticonvulsant activity of hydrazones, Schiff and Mannich bases of isatin derivatives. European Journal of Pharmaceutical Sciences, 16: 129-132.

Uruk T, Kahraman S, 2017. Yaban Mersini (Vaccinium myrtillus) Şarabının Antioksidan Aktivitesinin Araştırılması. Journal of the Institute of Science and Technology, 7(4): 77-83.

Verma M, Pandeya SN, Singh KN, Stables JP, 2004. Anticonvulsant activity of Schiff bases of isatin derivatives. Acta Pharmaceutica, 54: 49-56.

Wanasundara P, Shahidi F, 2005. Antioxidants: Science, technology, and applications. Bailey's industrial oil and fat products. 